\title{
Tobacco industry: a barrier to social justice
}

\author{
Kelsey Romeo-Stuppy (D) ,' Laurent Huber (D) , ${ }^{1}$ Brigit Toebes, ${ }^{2}$ Valerie Yerger (D) , \\ Flavia Senkubuge ${ }^{4}$
}

\begin{abstract}
${ }^{1}$ Action on Smoking and Health, Washington, DC, USA

${ }^{2}$ Department of International Law, Faculty of Law, Rijksuniversiteit Groningen, Groningen, The Netherlands ${ }^{3}$ Department of Social and Behavioral Sciences, University of California, San Francisco, San Francisco, California, USA ${ }^{4}$ Department of Health Sciences, University of Pretoria, Pretoria, South Africa
\end{abstract}

\section{Correspondence to}

Kelsey Romeo-Stuppy, Action on Smoking and Health, Washington, District of Columbia, USA: romeo-stuppyk@ash.org

Received 7 June 2021 Accepted 17 November 2021

Check for updates

(C) Author(s) (or their employer(s)) 2022. No commercial re-use. See rights and permissions. Published by BMJ.

To cite: Romeo-Stuppy K,

Huber $\mathrm{L}$, Toebes $\mathrm{B}$, et al.

Tob Control

2022:31:352-354
Social justice recognises the need for the 'the distribution of wealth, opportunities, and privileges within a society'. ${ }^{1}$ According to the United Nations, social justice is an underlying principle for peaceful and prosperous coexistence within and among nations. ${ }^{2}$ Social justice can also refer to the balance between individuals and society ${ }^{3}$; if we assume that governments play a major role in society, then their obligation to protect individuals from third parties ${ }^{4}$ (eg, the tobacco industry) becomes one of their key responsibilities in maintaining social justice. Furthermore, the actions of the government in one country can negatively impact social justice in another.

\section{HOW IS TOBACCO ANTITHETICAL TO SOCIAL JUSTICE?}

Tobacco is the leading cause of preventable death, annually killing more than 8 million people worldwide. ${ }^{5}$ These deaths are caused by the actions of the tobacco industry, an industry that has been allowed to impede social justice.

For decades, tobacco companies have been aggressively targeting certain vulnerable populations. For example, within the USA, African-Americans have been inundated with advertisements for menthol cigarettes. ${ }^{6}$ As a result, $85 \%$ of African-Americans who smoke use menthol cigarettes. ${ }^{7}$ As the Centers for Disease Control and Prevention (CDC) stated, 'Although African Americans usually smoke fewer cigarettes and start smoking cigarettes at an older age, they are more likely to die from smokingrelated diseases than Whites', ${ }^{8}$ in large part due to compounding social inequities such as lack of access to healthcare and racism in the healthcare system. ${ }^{9}$ This is just one example of an intersection between social justice and tobacco. Commercial tobacco is also a barrier to social justice for youth, ${ }^{10}$ women, ${ }^{11}$ the lesbian, gay, bisexual, transgender (LGBT+) community, ${ }^{12}$ Indigenous people, ${ }^{13}$ people with lower income ${ }^{14}$ and people with less education. ${ }^{15}$

The tobacco-related burden of disease and death has also shifted from high-income countries to lower income countries, with over $80 \%$ of the world's 1.3 billion tobacco users now living in low-income and middle-income countries. ${ }^{1617}$ This in large part due to tobacco industry marketing, industry influence in policy making and aggressive litigation tactics. ${ }^{18}$ For example, some high-income countries allow tobacco corporations to manufacture cigarettes that were deemed unsafe for the market in their countries and export them to other, usually lower income countries. ${ }^{19}$ An investigative report concluded, 'the cigarettes produced on Swiss soil and sold in Morocco are much stronger, more addictive and more toxic than those sold in Switzerland or France'. ${ }^{19}$ All of these burdens create a situation where the most vulnerable are left to deal with the consequences of tobacco use.

\section{INTERSECTIONS WITH OTHER HEALTH/SOCIAL JUSTICE ISSUES}

Highlighting connections with other health and social justice issues allows for partnerships with advocates in other fields and creates linkages for government officials, so they can further tobacco control and intersecting issues such as the nonexhaustive examples further.

\section{Non-communicable diseases (NCDs)}

NCDs kill approximately 41 million people each year, equivalent to $71 \%$ of all deaths globally. ${ }^{20}$ Tobacco use is the only risk factor shared by all four main categories of NCDs-cardiovascular disease, cancer, chronic lung disease and diabetes-and accounts for nearly one in six deaths from NCDs. ${ }^{21}$ In addition to the large-scale negative health impacts, NCDs reflect a challenge for social justice; $77 \%$ of all NCD deaths are now in low-income and middle-income countries. ${ }^{22}$

\section{Women's rights}

Around the world, women use tobacco at lower rates than men. ${ }^{23}$ However, tobacco use among women is decreasing at a significantly lower rate, ${ }^{23}$ and in some countries, women are smoking more. For example, in France, between 1980 and 2012, despite a $6.3 \%$ decrease in smoking among men, there was a $75 \%$ increase in smoking among women and a nine times increase in tobacco deaths among women in 2010 than in $1980 .^{24} 25$ Globally, women are still the main victims of secondhand smoke, and more women than men are harmed or die from exposure to it. ${ }^{26}$ Furthermore, unsafe work environments contribute to women dying from secondhand smoke, despite their being less likely to smoke themselves. ${ }^{26}$

\section{COVID-19}

During the COVID-19 pandemic, commercial tobacco and the actions of the tobacco industry are even more of a blight on society, as tobacco is a known risk factor for respiratory diseases and increases their severity. Many of the groups most harmed by tobacco are also at risk for worse outcomes when infected with COVID-19. AfricanAmericans are more likely to contract COVID-19 and are 1.9 times more likely to die from it than white Americans. ${ }^{27}$ Lower income countries ${ }^{28}$ and people of lower socioeconomic status around 
the world ${ }^{29}$ have been, and still are, particularly vulnerable to COVID-19. Addressing tobacco can help protect these groups from both tobacco-related diseases and increased mortality risk from COVID-19.

\section{Environmental justice}

The ecological footprint of commercial tobacco is comparable with that of entire countries. ${ }^{30}$ From tobacco cultivation ${ }^{31}$ to cigarette manufacturing, distribution, consumption and the production of wastes and emissions (including cigarette butts and packaging waste), every stage in the global tobacco supply chain involves considerable resource inputs. ${ }^{32}$ Unfortunately, lower income countries and the most vulnerable communities bear the most burden. ${ }^{33}$

\section{RECOMMENDATIONS}

Commercial tobacco and the tobacco industry are harmful in myriad ways. We argue that a social justice approach to tobacco control can help counter these harms.

\section{The Framework Convention on Tobacco Control (FCTC)}

First and foremost, every country can and should become a Party to and implement all the measures of the FCTC. In addition, Parties should consider one article that is often overlooked, Article 2.1, which calls on governments to go further than the measures specified in the treaty 'in order to better protect human health'. ${ }^{34}$ Some countries and governments have already accelerated the implementation of the FCTC by boldly implementing initiatives such as flavour bans, ${ }^{35}$ tax policies ${ }^{36}$ and standardised packaging ${ }^{37}$; some of these initiatives go as far as to ban the sale of commercial tobacco products, a movement that is gaining momentum. ${ }^{38}$ Other governments have already adopted 'tobacco free' or extremely low prevalence targets; for example, Finland has announced an action plan to achieve less than $2 \%$ smoking prevalence by $2040 .{ }^{39}$

\section{Human rights mechanisms}

In addition to using public health measures to end the tobacco epidemic, governments and civil society should employ the power of human rights mechanisms. There are several international human rights treaties that are relevant to tobacco control and social justice, and countries are obligated to report to those treaties about the human rights situation in their countries. However, those reports seldom include tobacco. The reports are submitted to the committee for each treaty, which in turn makes recommendations back to the country that submitted the report. Advocates have the opportunity to submit reports to draw each treaty committees' attention to the way tobacco devastates the populations the treaties are bound to protect.

One study reviewed the Concluding Observation of the Committee on Economic, Social, and Cultural Rights. When a tobacco-specific parallel report was submitted, the Committee included tobacco in its concluding observations 28.9\% of the time. When no parallel report was submitted, tobacco was mentioned a mere $7 \%$ of the time. ${ }^{40}$

\section{Breaking down silos}

Forming partnerships between tobacco and social justice movements is also crucial. The UN Human Rights Council adopted a resolution that encourages government parties to work across issue areas to achieve the right to health. ${ }^{41}$ Advocates can use this resolution to urge government officials to work across issues areas, for example, inviting local departments of both health and justice to support tobacco control policies.

\section{Combatting tobacco industry 'social justice' messages}

Tobacco corporations use corporate social responsibility (CSR) as a way to portray themselves as champions for social justice; for example, Altria recently gave a $\$ 5$ million donation to 'fight racial inequality'. ${ }^{42}$ FCTC Article 5.3 guidelines explain that the 'tobacco industry conducts activities described as socially responsible to distance its image from the lethal nature of the product it produces and sells...' ${ }^{43}$ Article 13 guidelines of the FCTC recommend banning CSR. ${ }^{44}$

A social justice approach can help counter these messages. Advocates in San Francisco framed their campaign to ban menthol and other flavours as a social justice issue, which resulted in an unanimously passed menthol restriction, despite industry pushback. ${ }^{45}$

\section{Litigation}

Social justice arguments add additional support to legal cases involving tobacco control. When a smoke-free air law in Peru was challenged, lawyers used human rights law (and focused on the right to health) to bolster their argument and ultimately won the case, leaving the law intact ${ }^{46}$ and protecting vulnerable people from secondhand smoke, a victory for social justice. ${ }^{47}$

Recently in the USA, several civil society organisations sued the US Food and Drug Administration (FDA) for its inaction on menthol cigarettes. ${ }^{48}$ In addition to the lawsuit, 96 organisations submitted a report to the Committee on the Elimination of Racial Discrimination to bring attention to the negative impacts of menthol on the rights of African-Americans. ${ }^{49}$ The goal of the report is to encourage the Committee to hold the US government accountable for protecting its citizens from the harms of menthol cigarettes. The legal arguments in the lawsuit against the FDA were largely based on human rights and social justice. The FDA agreed to propose a rule to ban menthol, and the court will continue to monitor its progress. ${ }^{50}$ This is an excellent example of how affirmative litigation can be fruitful both for tobacco control and to bolster social justice, as well as an example of how domestic tobacco control advocacy can be bolstered by a human rights approach.

\section{CONCLUSION}

Tobacco control and social justice are intrinsically connected. By addressing tobacco, we make progress towards a more socially equitable society. Tobacco control advocates should increase their use of tools that human rights and social justice advocates already frequently use: human rights treaty body reporting, international best practices (specifically the FCTC), litigation and legislation. These tools can help ensure that the right to health is protected for all people, but especially for vulnerable populations such as people of lower socioeconomic status, people with less education, racial minorities, the LGBT community and especially for those people who are at the intersections of these groups.

The body of knowledge at the nexus of social justice and tobacco control has grown by leaps and bounds in recent years. Now more than ever, it is apparent that by incorporating social justice and human rights language, arguments and mechanisms into tobacco control efforts, we can make progress to end the tobacco epidemic and improve social justice.

Twitter Kelsey Romeo-Stuppy @AshOrg and Brigit Toebes @brigittoebes 
Contributors All authors contributed to the drafting and editing of this article and approved the final version for publication.

Funding The authors have not declared a specific grant for this research from any funding agency in the public, commercial or not-for-profit sectors.

Competing interests None declared.

Patient consent for publication Not applicable.

Provenance and peer review Commissioned; externally peer reviewed.

\section{ORCID iDs}

Kelsey Romeo-Stuppy http://orcid.org/0000-0002-6961-8031

Laurent Huber http://orcid.org/0000-0003-3548-1978

Valerie Yerger http://orcid.org/0000-0003-2469-402X

\section{REFERENCES}

1 Oxford L. Available: https://www.lexico.com/definition/social_justice [Accessed 11 Oct 2021].

2 United Nations. World day of social justice, 2017. Available: https://www.un.org/ development/desa/dspd/international-days/world-day-of-social justice/world-dayofsocial-justice-2017.html [Accessed 01 Jun 2021].

3 The International Forum for Social Development. Social justice in an open world: the role of the United nations. Available: https://www.un.org/esa/socdev/documents/ifsd/ SocialJustice.pdf [Accessed 15 Apr 2021].

4 UN Committee on Economic, Social and Cultural Rights (CESCR). General Comment No. 14: the right to the highest attainable standard of health (art. 12 of the covenant), 2000. Available: https://www.refworld.org/docid/4538838d0.html [Accessed 10 Aug 2021].

5 World Health Organization,. Tobacco fact sheet. Available: https://www.who.int/newsroom/fact-sheets/detail/tobacco [Accessed 19 Mar 2021].

6 Yerger VB, Przewoznik J, Malone RE. Racialized geography, corporate activity, and health disparities: tobacco industry targeting of inner cities. J Health Care Poor Underserved 2007;18:10-38.

7 United States Food and Drug Administration. FDA commits to evidence-based actions aimed at saving lives and preventing future generations of smokers. Available: https:// www.fda.gov/news-events/press-announcements/fda-commits-evidence-basedactions-aimed-saving-lives-and-preventing-future-generations-smokers [Accessed 15 Apr 2021].

8 Centers for Disease Control and Prevention. African Americans and tobacco use. Available: https://www.cdc.gov/tobacco/disparities/african-americans/index.htm [Accessed 15 Apr 2021].

9 Ho JY, Elo IT. The contribution of smoking to black-white differences in U.S. mortality. Demography 2013;50:545-68.

10 van der Eijk Y, Tan GPP. Tobacco industry targeting of health-conscious youth with 'lighter' cigarettes: the case of Singapore. Tob Control 2021;30:e20-6.

11 Houghton F, Moran Stritch M, O'Doherty D. EU tobacco controls and the importance of gender : time to ban slim and superslim cigarettes. Malta Journal of Health Sciences 2020;7:39-48.

12 Harlow AF, Lundberg D, Raifman JR, et al. Association of coming out as Lesbian, gay, and Bisexual+ and risk of cigarette smoking in a nationally representative sample of youth and young adults. JAMA Pediatr 2021;175:56-63.

13 Waa A, Maddox R, Nez Henderson P. Big tobacco using trojan horse tactics to exploit Indigenous peoples. Tob Control 2020;29:e132.

14 Hiscock R, Bauld L, Amos A, et al. Socioeconomic status and smoking: a review. Ann NY Acad Sci 2012;1248:107-23.

15 Hitchman SC, Fong GT, Zanna MP, et al. Socioeconomic status and smokers' number of smoking friends: findings from the International tobacco control (ITC) four country survey. Drug Alcohol Depend 2014;143:158-66.

16 World Health Organization. Available: Tobaccohttps://www.who.int/news-room/ factsheets/ detail/tobacco [Accessed 28 Apr 2021].

17 Bollyky TJ, Templin T, Cohen M, et al. Lower-income countries that face the most rapid shift in noncommunicable disease burden are also the least prepared. Health Aff 2017;36:1866-75.

18 Gilmore $A B$, Fooks G, Drope J, et al. Exposing and addressing tobacco industry conduct in low-income and middle-income countries. Lancet 2015;385:1029-43.

19 Public Eye. The blazing success of Swiss cigarettes in Africa, 2019. Available: http:// stories.publiceye.ch/tobacco/ [Accessed 07 May 2021].

20 World Health Organization. Noncommunicable diseases. Available: https://www.who. int/news-room/fact-sheets/detail/noncommunicable-diseases [Accessed 22 Apr 2021]

21 Campaign for Tobacco Free Kids, Global Issues. Non-communicable diseases. Available: https://www.tobaccofreekids.org/what-we-do/global/non-communicablediseases [Accessed 22 Apr 2021].

22 World Health Organization. Non-communicable diseases. Available: https://www.who int/news-room/fact-sheets/detail/noncommunicable-diseases [Accessed 22 Apr 2021]

23 World Health Organization. 10 facts on women and tobacco. Available: https://www. who.int/gender/documents/10facts_gender_tobacco_en.pdf
$24 \mathrm{Ng} \mathrm{M}$, Freeman MK, Fleming TD, et al. Smoking prevalence and cigarette consumption in 187 countries, 1980-2012. JAMA 2014;311:183-92.

25 Ribassin-Majed L, Hill C. Trends in tobacco-attributable mortality in France. Eur J Public Health 2015;25:824-8.

26 World Health Organization. Worldwide burden of disease from exposure to secondhand smoke. Available: https://www.who.int/quantifying_ehimpacts/publications/ shsarticle2010/en/ [Accessed 18 May 2021].

27 Centers for Disease Control and Prevention. Risk for COVID-19 infection, hospitalization, and death by Race/Ethnicity. Available: https://www.cdc.gov/ coronavirus/2019-ncov/covid-data/investigations-discovery/hospitalization-death-byrace-ethnicity.html [Accessed $02 \mathrm{Apr} 2021$ ].

28 Bong C-L, Brasher C, Chikumba E, et al. The COVID-19 pandemic: effects on low- and middle-income countries. Anesth Analg 2020;131:86-92.

29 Bambra C, Riordan R, Ford J, et al. The COVID-19 pandemic and health inequalities. J Epidemiol Community Health 2020;121:jech-2020-214401-68.

30 Data W. Greenhouse gases emission by country. Available: https://www.worlddata. info/greenhouse-gas-by-country.php [Accessed 19 Mar 2021].

31 Unfairtobacco. Tanzania- tobacco takes its toll in the Miombo Woodlands. Available: https://unfairtobacco.org/wp-content/uploads/2018/12/Mangora_Unfairtobacco_ Tanzania_deforestation.pdf [Accessed 18 May 2021].

32 Unfairtobacco. Bangladesh- tobacco ruins soil and water along the Matamuhuri river. Available: https://unfairtobacco.org/wp-content/uploads/2018/12/Akhter_ Unfairtobacco_Bangladesh_pesticide-pollution.pdf [Accessed 18 May 2021].

33 Zafeiridou M, Hopkinson NS, Voulvoulis N. Cigarette smoking: an assessment of tobacco's global environmental footprint across its entire supply chain, and policy strategies to reduce it. Available: https://www.who.int/fctc/publications/WHO-FCTC Enviroment-Cigarette-smoking.pdf?ua=1\&ua=1

34 World Health Organization. Framework convention on tobacco control, article 2.1 World Health Organization, 2003. http://www.who.int/fctc/en/

35 Erinoso O, Clegg Smith K, lacobelli M, et al. Global review of tobacco product flavour policies. Tob Control 2021;30:373-9.

36 Chaloupka FJ, Straif K, Leon ME, et al. Effectiveness of tax and price policies in tobacco control. Tob Control 2011:20:235-8.

37 World Health Organization. Tobacco plain packaging: global status update. Geneva: World Health Organization, 2018. https://apps.who.int/iris/bits.

38 See for example, Sharp S. Los Angeles times. Beverly hills becomes the first U.S. city to end most tobacco sales. Available: https://www.latimes.com/local/lanow/la-me-Inbeverly-hills-ends-tobacco-sales-20190604-story.html [Accessed 28 May 2021].

39 WHO Framework Convention on Tobacco Control. Finland - action plan to make the country smoke-free by 2040, 2014. Available: https://www.who.int/fctc/ implementation/news/news Fin/en/ [Accessed 29 Mar 2021].

40 Dresler C, Henry K, Loftus J, et al. Assessment of short reports using a human rightsbased approach to tobacco control to the Commitee on economics, cultural and socia rights. Tob Control 2018;27:385-9.

41 UN Human Rights Council. The right of everyone to the enjoyment of the highest attainable standard of physical and mental health in the implementation of the 2030 agenda for sustainable development. Available: https://documents-dds-ny.un.org/doc/ UNDOC/GEN/G17/190/18/PDF/G1719018.pdf?OpenElement [Accessed 23 Jun 2017].

42 Business Wire. Altria announces five million dollar donation to fight racial inequality, 2020. Available: https://www. businesswire.com/news/home/20200605005256/en/ Altria-Announces-Five-Million-Dollar-Donation-to-Fight-Racial-Inequality [Accessed 20 Jul 2021]

43 World Health Organization. Guidelines for implementation of article 5.3 of the who framework convention on tobacco control on the protection of public health policies with respect to tobacco control from commercial and other vested interests of the tobacco industry. Available: https://www.who.int/fctc/guidelines/article_5_3.pdf

44 World Health Organization. Guidelines for implementation of article 13 of the WHO framework convention on tobacco control (tobacco advertising, promotion and sponsorship). Available: https://www.who.int/fctc/guidelines/article_13.pdf?ua=1

45 Mills SD, McGruder CO, Yerger VB. The African American tobacco control leadership Council: advocating for a menthol cigarette ban in San Francisco, California. Tob Control 2021;30:e150-3.

465000 Citizens v. Article 3 of law N. ${ }^{\circ} 28705$, EXP. N. ${ }^{\circ} 00032-2010-P I / T C$. Tribunal Constitucional del Perú. Constitutional Court, 2011.

47 Center for Disease Control and Prevention (CDC). Cigarette smoking and tobacco use among people of low socioeconomic status, 2018. Available: https://www.cdc.gov/ tobacco/disparities/low-ses/index.htm [Accessed 12 Jun 2021].

48 Action on Smoking and Health. National medical association (NMa) joins AATCLC, AMA and ash in lawsuit against the FDA. Available: https://ash.org/nma-joins-lawsuitagainst-fda/ [Accessed 28 May 2021].

49 Action on Smoking and Health. National medical association (NMa) joins AATCLC, AMA and ash in lawsuit against the FDA. Available: https://ash.org/nma-joins-lawsuitagainst-fda/ [Accessed May 2021].

50 U.S. Food and Drug Administration. FDA commits to evidence-based actions aimed at saving lives and preventing future generations of smokers, 2021. Available: https://www.fda.gov/ news-events/press-announcements/fda-commits-evidence-based-actions-aimed-savinglives-and-preventing-future-generations-smokers [Accessed 23 Aug 2021]. 